\title{
Micropropagation of the Rare Lakeside Daisy (Hymenoxys acaulis var. glabra)
}

\author{
James R. Ault \\ Chicago Botanic Garden, 1000 Lake Cook Road, Glencoe, IL 60022
}

Additional index words. Asteraceae, federally threatened, tissue culture, shoot production, auxin, cytokinin

\begin{abstract}
Shoot tip and stem segment explants collected from greenhouse-maintained plants of Hymenoxys acaulis var. glabra were cultured in vitro for shoot initiation on a Murashige and Skoog (MS) medium supplemented with $30 \mathrm{~g} \cdot \mathrm{L}^{-1}$ sucrose, $2.5 \mu \mathrm{M} \mathrm{BA}$, and $7 \mathrm{~g} \cdot \mathrm{L}^{-1}$ agar at a $\mathrm{pH}$ of 5.7. Unbranched shoot explants were subcultured to MS medium with $0.0,0.5,1,2,4$ or $8 \mu \mathrm{M}$ BA for shoot proliferation. A maximum of 10.3 shoots per explant was produced on the medium with $2.0 \mu \mathrm{M} B A$. Nonrooted shoots were subcultured to MS medium with $0.0,0.5,2$, or $8 \mu \mathrm{M}$ K-IBA for rooting. Maximum rooting was $90 \%$ on MS medium with $0.5 \mu \mathrm{M}$ K-IBA. Rooted shoots were greenhouse-acclimatized for 10 days. Overall survival was 75\%. Chemical names used: 6-benzyl adenine (BA); potassium salt of indole-3-butyric acid (K-IBA).
\end{abstract}

Hymenoxys acaulis (Pursh) Parker var. glabra (Gray) Parker [also known as Hymenoxys herbacea (Greene) Cusick and Tetraneuris herbacea Greene] is an herbaceous perennial known as the lakeside daisy (Fig. 1). Listed as threatened by the U.S. federal government and as endangered by the states of Illinois and Ohio (U.S. Fish and Wildlife Service, 1990), it is endemic to the Great Lakes region of North America, with populations in Michigan and Ohio in the United States, and in Ontario, Canada.

Natural stands of the lakeside daisy occurred historically in Illinois, but the last known population was destroyed in 1981 . However, in the late 1970s three plants were collected from this population and maintained in a private garden until propagated for a restoration project (DeMauro, 1993). The plants were repeatedly cross-pollinated for 6 years, but failed to produce seed. This species is selfincompatible, so the Illinois plants are presumably of the same mating type (DeMauro, 1993). Therefore, the genetic integrity of the remaining Illinois plants can only be maintained through vegetative propagation.

The lakeside daisy forms a persistent basal rosette that spreads vegetatively from rhizomes. It can be propagated by division or rooted cuttings. However, its creeping rootstock limits the number of divisions or cuttings that can be taken from a single plant. Plants can be difficult to maintain in a garden setting or in pots, as they are sensitive to poor soil drainage and overwatering. Therefore, a micropropagation study utilizing the Illinois genotype was initiated as an alternative means of propagating the lakeside daisy. To my knowledge there are no other reports on the micropropagation of this taxon.

Received for publication 16 Jan 2001. Accepted for publication 20 Mar 2001. Lisle, Ill. Container-grown plants of the Illinois geno-
type were obtained from The Morton Arbore-
tum (Lisle, Ill.) in Aug. 1998 and maintained
in a greenhouse. Individual shoots up to $5 \mathrm{~cm}$
in length were removed in July and Aug. 1999 ,
and all fully expanded leaves and most of the
leaf primordia were removed. Stem segments
were surface-disinfested in $1.0 \%$ sodium hy-
pochlorite containing $0.1 \%$ Tween 80 for 12
min and then rinsed twice for 10 min total in
sterile deionized water. Explants consisting of
shoot tips or stem segments (each with three to
five nodes) $\approx 1 \mathrm{~cm}$ in length were individually
placed basal end down in $25 \times 150$-mm culture
tubes containing $10 \mathrm{~mL}$ of MS basal salts and
vitamins (Murashige and Skoog, 1962 ), 30
g. $\mathrm{L}^{-1}$ sucrose and $2.5 \mu \mathrm{M}$ benzyladenine (BA).
Medium $\mathrm{pH}$ was adjusted to 5.7 prior to adding $7.0 \mathrm{~g} \cdot \mathrm{L}^{-1}$ Sigma A 1296 agar (Sigma Chemical Co., St. Louis). Culture tubes were capped with polypropylene caps and autoclaved at $121^{\circ} \mathrm{C}$ for $15 \mathrm{~min}$.

Capped culture tubes were sealed with Parafilm (Pechiney Plastic Packaging, Menasha, Wis.), then placed upright and maintained at $22^{\circ} \mathrm{C}$ under a 14-h photoperiod with a photosynthetic photon flux (PPF) of 15 to 40 $\mu \mathrm{mol} \cdot \mathrm{m}^{-2} \cdot \mathrm{s}^{-1}$ [measured with a LI-190SA Quantum Sensor (LI-COR, Lincoln, Nebr.)] provided by two 40-W cool-white fluorescent lamps.

The primary explants were cultured for 6 weeks; then the original shoot segments and axillary shoots were excised and recultured every 4 weeks for six to eight culture periods prior to the rooting study and for 8 to 11 culture periods prior to the shoot proliferation study. Leaves were removed from the lower half of each explant with each subculture as they curled downwards and pushed the explants out of the medium. Individual, unbranched shoot explants $(2 \mathrm{~cm})$ were cultured on MS medium with $0,0.5,1,2,4$, or $8 \mu \mathrm{M}$ BA for shoot proliferation. After 4 weeks of culture, shoots were harvested, and the number of axillary shoots recorded. Shoots $(2-3 \mathrm{~cm})$ were rooted on MS medium with $0,0.5,2$, or $8 \mu \mathrm{M}$ of the potassium salt of indole-3-butyric $\operatorname{acid}(\mathrm{K}-\mathrm{IBA})$. Percent rooting and the number of roots per shoot were recorded after 4 weeks.

Individual shoots were rooted on MS medium with $0.5 \mu \mathrm{M}$ K-IBA for $20 \mathrm{~d}$, rinsed free of medium, and planted in a 72-cell plug tray containing 1 Turface ${ }^{\circledR}$ (Profile Products LLC, Buffalo Grove, Ill.) : 1 fine sand : 1 perlite : 2 Strong-Lite Universal Mix (Strong-lite Products Corp., Pine Bluff, Ark.) (by volume). The tray was covered with a clear plastic dome and placed in a shaded greenhouse on 1 Aug. 2000. The dome was removed after $3 \mathrm{~d}$, and the tray moved to the edge of a shaded mist bench for 1 week, and then to an open greenhouse bench.

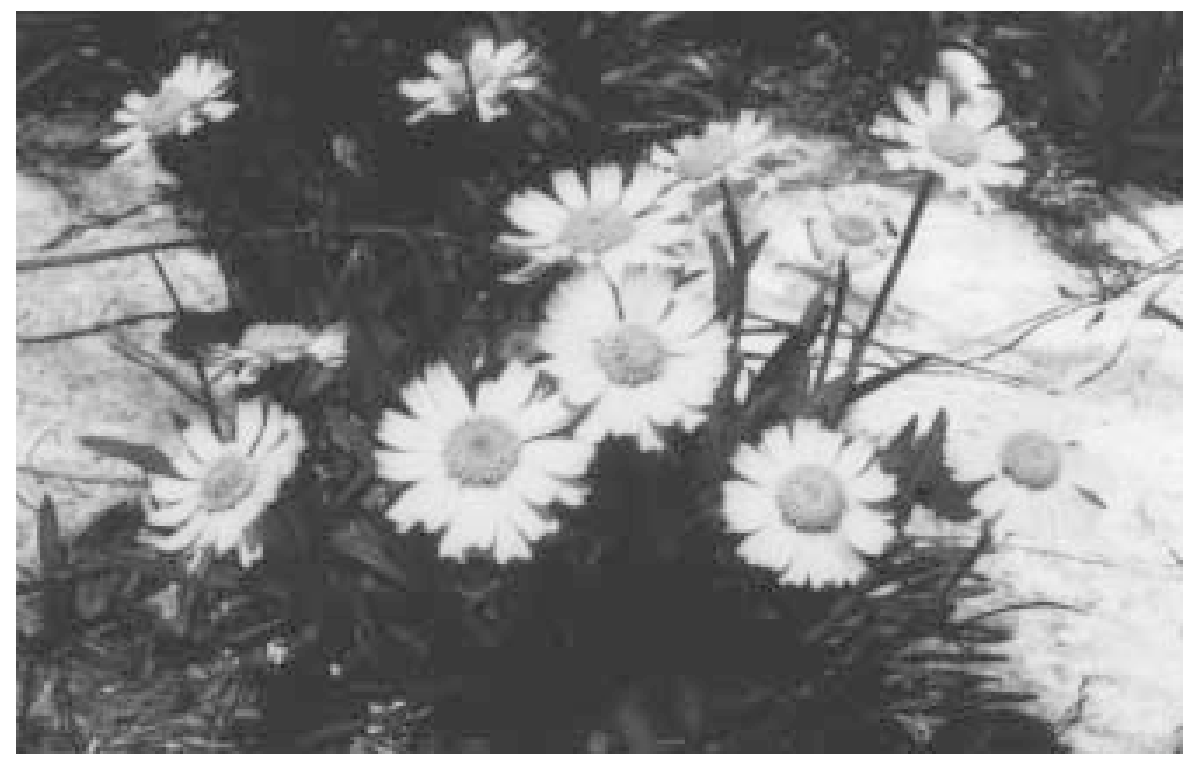

Fig. 1. The lakeside daisy (Hymenoxys acaulis var. glabra) growing inter situ at The Morton Arboretum,

( 
Percent survival was recorded $30 \mathrm{~d}$ after plants were removed from tissue culture. This study was conducted once, utilizing 80 explants.

Forty explants were randomly assigned to each shoot proliferation and rooting treatment. Experiments were conducted twice $(n=80)$. Data were subjected to analysis of variance, and means separated according to the Student-Newman-Keul test (Sokal and Rohlf, 1969). Percent rooting was analyzed with the $\mathrm{G}$ statistic, comparing the individual auxin treatments to the control (no K-IBA). Data were analyzed with CoStat statistical software (CoHort Software, Berkeley, Calif.).

\section{Results and Discusssion}

Explants on BA-free medium produced one unbranched shoot each, indicating strong apical dominance (Table 1). BA stimulated the production of axillary shoots regardless of concentration. BA at $2 \mu \mathrm{M}$ induced significantly more axillary shoots (10.3 shoots per explant) than did the other treatments (Table 1). BA has been utilized to stimulate axillary shoot production in other taxa of the Asteraceae. In comparison, optimal shoot proliferation rates were 5.3 shoots per single node explant as induced by $4.43 \mu \mathrm{M}$ BA in Achillea asplenifolia VENT. (Wawrosch, 1994); 19.8 shoots per shoot explant as induced by $2.7 \mu \mathrm{M}$ BA in Liatris spicata (L.) Willd. (Stimart and Harbage, 1989); and 7.2 shoots per single node explant as induced by $3 \mu \mathrm{M}$ BA in Dyssodia pentacheta (D.C.) Robins (Zimmerman et al., 1991). BA appears effective in stimulating axillary shoot proliferation in taxa of the Asteraceae, but it is recommended that a range of concentrations be tested to optimize shoot production.

Treatment of Hymenoxys acaulis var. glabra shoot explants with 4 or $8 \mu \mathrm{M} \mathrm{BA}$ stimulated significantly more shoots than did the control, but also stimulated basal callusing on most of the explants (Table 1). Therefore, these and higher concentrations of BA are not recommended for shoot proliferation in this taxon, as callus production could interfere
Table 1. Shoot production from single shoot explants of Hymenoxys acaulis var. glabra after 4 weeks of culture on MS medium with various BA concentrations.

\begin{tabular}{lcc}
\hline $\begin{array}{l}\text { BA } \\
(\mu \mathrm{M})\end{array}$ & $\begin{array}{c}\text { Mean no. } \\
\text { shoots/explant }\end{array}$ & Callus $^{\mathrm{z}}$ \\
\hline 0.0 & $1.0 \mathrm{~d}^{\mathrm{y}}$ & - \\
0.5 & $5.2 \mathrm{c}$ & - \\
1.0 & $7.4 \mathrm{~b}$ & - \\
2.0 & $10.3 \mathrm{a}$ & - \\
4.0 & $8.9 \mathrm{~b}$ & + \\
8.0 & $8.6 \mathrm{~b}$ & + \\
\hline
\end{tabular}

${ }^{\mathrm{z}}$ Callus present $(+)$ or absent $(-)$.

${ }^{\mathrm{y}}$ Mean separation by Student-Newman-Keul test, $P$ $\leq 0.05 ; \mathrm{n}=78$ to 80 .

with subsequent rooting and acclimatization.

$\mathrm{K}$-IBA at all three concentrations tested was significantly more effective in inducing rooting than no K-IBA (Table 2). Maximum rooting was $90 \%$ for the shoots treated with 0.5 $\mu \mathrm{M}$ K-IBA. The mean number of roots per shoot was significantly increased by treatment with 0.5 or $2.0 \mu \mathrm{M} \mathrm{K}$-IBA in comparison with the other two treatments (Table 2). IBA is effective for the rooting of other members of the Asteraceae. Centaurea junoniana shoots rooted $100 \%$ when treated with $0.05 \mu \mathrm{M}$ IBA (Hammatt and Evans, 1985), and the greatest number of roots produced per shoot for Liatris spicata was stimulated by $5 \mu \mathrm{M} \mathrm{K-IBA} \mathrm{(Stimart}$ and Harbage, 1989).

Of the 69 rooted shoots removed from tissue culture, $52(75 \%)$ survived the greenhouse acclimatization process. The initial utilization of a plastic dome over the rooted shoots may have kept the relative humidity (RH) and/or temperature too high for this taxon, as plants began senescing within the first $3 \mathrm{~d}$; once the plastic dome was removed and the plants placed in an environment with lower RH and temperature, plant losses diminished. Seven months after removal from tissue culture, the plants visually appeared very uniform.

Plants of the Illinois genotype are being utilized for display and restoration research at both The Morton Arboretum and at Chicago Botanic Garden. Propagation and maintenance
Table 2. Percent rooting and the number of roots produced per rooted shoot from shoot explants of Hymenoxys acaulis var. glabra after 4 weeks of culture on MS medium with K-IBA.

\begin{tabular}{lcc}
\hline $\begin{array}{l}\text { K-IBA } \\
(\mu \mathrm{M})\end{array}$ & $\begin{array}{c}\text { Rooting } \\
(\%)\end{array}$ & $\begin{array}{c}\text { Mean no. roots/ } \\
\text { rooted shoot }\end{array}$ \\
\hline 0.0 & 68 & $3.1 \mathrm{~b}^{\mathrm{z}}$ \\
0.5 & $90^{* *}$ & $17.3 \mathrm{a}$ \\
2.0 & $86^{*}$ & $18.3 \mathrm{a}$ \\
8.0 & $85^{*}$ & $5.0 \mathrm{~b}$ \\
\hline
\end{tabular}

${ }^{\mathrm{z}}$ Mean separation by Student-Newman-Keul test, $P$ $\leq 0.05 ; \mathrm{n}=68$ to 75 .

${ }^{*},{ }^{* *}$ Significantly different from the control at $P \leq$ 0.05 or 0.01 , respectively, by the G statistic.

of this germplasm is a conservation priority. Micropropagation offers an alternative means of propagating the rare plant Hymenoxys acaulis var. glabra. I recommend $2.0 \mu \mathrm{M} \mathrm{BA}$ for shoot multiplication, $0.5 \mu \mathrm{M}$ K-IBA for rooting, and moderate $\mathrm{RH}$ for subsequent acclimatization of rooted shoots.

\section{Literature Cited}

DeMauro, M.M. 1993. Relationship of breeding system to rarity in the lakeside daisy (Hymenoxys acaulis var. glabra). Conserv. Biol. 7:542-550.

Hammatt, N. and P.K. Evans. 1985. The in vitro propagation of an endangered species: Centaurea junoniana Svent. (Compositae). J. Hort. Sci. 60:93-97.

Murashige, T. andF. Skoog. 1962. A revised medium for rapid growth and bioassays with tobacco tissue cultures. Physiol. Plant. 15:473-479.

Sokal, R.R. and F.J. Rohlf. 1969. Biometry. 1st ed. Freeman, San Francisco.

Stimart, D.P. and J.F. Harbage. 1989. Shoot proliferation and rooting in vitro of Liatris spicata. HortScience 24:835-836.

U.S. Fish and Wildlife Service. 1990. Recovery plan for the Lakeside Daisy (Hymenoxys acaulis var. glabra). U.S. Fish Wildlife Serv., Twin Cities, Minn.

Wawrosch, C., B. Kopp, and W. Kubelka. 1994. In vitro propagation of Achillea asplenifolia VENT. Plant Cell Rpt. 14:161-164.

Zimmerman, T.W., F.T. Davies, and J.M. Zajicek. 1991. In vitro and macropropagation of the wildflower Dyssodia pentacheta (D.C.) Robins. HortScience 26:1555-1557. 